\title{
ETYCZNE I PRAWNE ASPEKTY DOPUSZCZALNOŚCI ABORCJI ZE WZGLĘDÓW EUGENICZNYCH
}

Prawne uregulowania aborcji stanowią przedmiot niesłabnącego zainteresowania ze strony zarówno przeciwników, jak i zwolenników legalności tego typu zabiegu. W opracowaniu poruszona zostanie problematyka względów eugenicznych, które zgodnie $\mathrm{z}$ unormowaniem przyjętym $\mathrm{w}$ ustawie o planowaniu rodziny, ochronie płodu ludzkiego i warunkach dopuszczalności przerywania ciąży z 7 stycznia 1993 r. stanowią jedną z przesłanek zezwalających na legalne przeprowadzenie aborcji. Wprawdzie polskie ustawodawstwo dopuszcza aborcję eugeniczną już od 1956 r., to jednak wciąż temat ten wydaje się aktualny, zwłaszcza w obliczu pojawiających się stale postulatów delegalizacji takiej możliwości. Pierwotnie (w latach 50.) nie nazywano tego wprost względami natury eugenicznej, ale ten przypadek zaliczany był do kategorii wskazań lekarskich.

Pojęcie eugeniki (gr. eugenes - dobrze urodzony) wprowadzone zostało do nauki przez F. Galtona, zainspirowanego teorią ewolucji K. Darwina i dotyczyło pierwotnie selektywnego rozmnażania, celem ulepszania gatunków, szczególnie w odniesieniu do cech dziedzicznych. W kolejnych latach F. Galton poprawił swoją definicję, uwzględniając specyfikę eugeniki pozytywnej, a więc zachęcającej do częstszego rozmnażania osobników najlepszych oraz eugeniki negatywnej zniechęcającej do rozmnażania mniej wartościowych osobników. ${ }^{1}$

Współcześnie przyjmuje się, że eugenika stanowi system poglądów zakładający możliwość doskonalenia dziedzicznych cech człowieka mającą na celu ustalenie i utrwalenie warunków, które pozwalają na rozwój cech dodatnich i ograniczenie cech ujemnych. ${ }^{2}$

Dopuszczalność przerwania ciąży ze względów eugenicznych nie jest współcześnie argumentowana dążeniem do udoskonalenia gatunku ludzkiego, lecz chodzi przede wszystkim o dobro kobiety i jej rodziny. Urodzenie upośledzonego

$1 \quad$ Za Wikipedia, data dostępu: 27.10.2012.

2 B. Petrozolin-Skowrońska (red.), Nowa Encyklopedia Powszechna PWN, t. 2, Warszawa 1995, s. 282. 
czy ciężko chorego dziecka może mieć niekorzystny wpływ na psychikę kobiety, jak również jej rodziny.

Niekiedy przywołuje się argument w postaci prawa człowieka do tego, ,aby nie być urodzonym" w sytuacji, kiedy jego egzystencję trudno będzie określić jako w pełni ludzką. Wskazuje się też prawo jednostki do odpowiedniej jakości życia. ${ }^{3}$ Nie uzasadnia się tego prawa $\mathrm{w}$ ten sposób, że wola kobiety ma wyższą wartość niż życie dziecka.

Diagnostyka prenatalna to dla wielu wspaniałe osiągnięcie medycyny, pozwalające uniknąć urodzenia chorego dziecka, ale dla wielu wybór, jakiego trzeba dokonać, związany jest z poważnymi dylematami natury etycznej, religijnej i emocjonalnej.

Aborcja jest tematem mocno politycznym, a w polskim parlamencie po raz kolejny zagościła bioetyka, pojawił się bowiem projekt nowelizacji wspomnianej wyżej ustawy przewidujący wykreślenie fragmentu zezwalającego na legalne przerwanie ciąży ze względów eugenicznych. W dyskursie publicznym często pojawiają się głosy afirmujące prawo kobiety do swobodnego wyboru przerwania bądź utrzymania ciąży. Pomijam jednak w tym miejscu spory i wątpliwości dotyczące statusu nasciturusa, koncentrując się przede wszystkim na problemie wyboru kobiety w przypadku względów eugenicznych, w aspekcie postulatu delegalizacji takiej aborcji.

W tym kontekście pojawia się bowiem pytanie, czy można wymagać od kobiety takich poświęceń, tzn. czy prawo może na kobietę nałożyć obowiązek (znosząc ten zapis) urodzenia chorego dziecka, co pociąga za sobą przecież pasmo daleko idących wyrzeczeń i poświęceń ze strony kobiety na rzecz innej osoby. A zatem czy prawo może nas zmuszać do takiego heroizmu?

Zasadnicze pytanie dotyczy więc poziomu wymagań moralnych, których spełnienie można uczynić przedmiotem prawnego obowiązku. A zatem jaki może być poziom wyrzeczeń, którego będziemy się domagać od każdego obywatela pod groźbą przymusu prawnego na rzecz innej jednostki? ${ }^{4}$

Jak wskazuje amerykańska filozof prawa J.J. Thomson, istnieje pewien poziom ofiarności na rzecz innych ludzi, który należy uznać za powszechny, ciążący na wszystkich moralny obowiązek. Autorka broni generalnie tezy, że prawnego zakazu aborcji nie można usprawiedliwiać nawet w sytuacji, jeśli poczynimy założenie, że nasciturus jest osobą ludzką już od poczęcia i przysługują mu uprawnienia moralne. Jej zdaniem, moralne prawo do życia nie jest równoznaczne $\mathrm{z}$ prawem do tego, aby nie zostać pozbawionym życia przez innych, ale z prawem do tego, aby nie

3 E. Zielińska, Przerywanie ciąży. Warunki legalności w Polsce i na świecie, Warszawa 1990, s. 123.

$4 \quad$ T. Pietrzykowski, Spór o aborcję. Etyczne problemy prawa, Katowice 2007, s. 81. 
zostać pozbawionym życia niesprawiedliwie. Moralne uzasadnienie zakazu aborcji wymaga zatem wykazania, że nasciturus jest człowiekiem posiadającym prawo od życia, a przerwanie ciąży stanowi nieusprawiedliwiony przypadek pozbawienia go życia. ${ }^{5}$

Przy czym wiele osób wykazuje znacznie dalej idące poświęcenia, wykraczające poza ten minimalny poziom wymaganej od każdego ofiarności, co świadczy o ich ponadprzeciętnej wartości i szlachetności. Nie oznacza to jednak, że innym jednostkom, które nie przekraczają tego minimalnego, wymaganego od wszystkich poziomu ofiarności możemy stawiać jakiekolwiek zarzuty natury moralnej. Szczególnego poziomu ofiarności i wielkich wyrzeczeń nie można bowiem uważać za powszechny moralny obowiązek. Etycy określają takie zjawisko mianem supererogacji. ${ }^{6}$ Chodzi o istnienie pewnej kategorii czynów, których dokonanie zasługuje na pochwałę moralną, lecz w przypadku ich niedokonania nie możemy mówić o moralnej dezaprobacie. Jako przykład podawane jest udzielenie pożyczki. Czyn polegający na jej darowaniu możemy uznać za szlachetny, co jednak nie oznacza, że oczekiwanie na zwrot pożyczki będzie zasługiwać na potępienie moralne. Jak to interpretuje T. Pietrzykowski: ,prawo nie powinno wymagać od nas czynów na takim poziomie, którego osiągnięcie nie może być przedmiotem powszechnego obowiązku moralnego. Czyn niebędący naruszeniem minimalnego poziomu powszechnych wymagań moralnych tym bardziej nie powinien być (...) przedmiotem nakazu prawnego. Rzecz sprowadza się zatem do stopnia wymagań, jakie mogą być stawiane jednostce przez prawo".7

Nawiązując do biblijnej przypowieści o miłosiernym Samarytaninie J.J. Thompson rozważa sytuację, kiedy ktoś jest przypadkiem świadkiem próby zabójstwa. Można się wówczas rzucić ofierze na ratunek, narażając tym samym własne życie w walce z napastnikiem, ale można po prostu zadzwonić na policję. W pierwszym przypadku mamy do czynienia $\mathrm{z}$ zachowaniem miłosiernego Samarytanina, kiedy to poświęcamy własne dobro dla innych, natomiast w drugim przypadku powiemy, że ktoś zachował się jak Dostatecznie Przyzwoity Samarytanin, czyli nie pozostał obojętny, jednak nie wykroczył poza minimum poświęcenia, jakiego można w takiej sytuacji oczekiwać od każdego człowieka. Ten przykład rodzi pytanie, czy prawo może nas obligować do postępowania jak miłosierny Samarytanin zdolny poświęcić siebie dla ratowania innych, czy też może nałożyć na nas obowiązek bycia Dostatecznie Przyzwoitym Samarytaninem, przy zachowaniu możliwości wyboru zachowania „lepszego”.

\footnotetext{
5 J.J. Thompson, In Defence of Abortion, „Philosophy and Public Affairs” 1971, t. 1, nr 1, s. 120.

6 Zob. A. Kaniowski, Supererogacja - zagubiony wymiar etyki. Czyny chwalebne w etykach uniwersalistycznych, Warszawa 1999.

$7 \quad$ T. Pietrzykowski, Spór o aborcję..., op. cit., s. 82-83.
} 
J.J. Fuller rozważając kwestię moralności aspiracji i moralności obowiązku zwraca uwagę, że w przypadku tej pierwszej punktem wyjścia są szczytowe osiągnięcia ludzkie, natomiast moralność obowiązku wychodzi od najniższego ich szczebla, formułując zasadnicze reguły, bez których istnienie uporządkowanego społeczeństwa jest niemożliwe, albo bez których uporządkowane społeczeństwo, które dąży do określonych celów nie jest w stanie ich osiągnąć. To moralność Starego Testamentu i dekalogu. Nie potępia ludzi, jeśli nie potrafią wykorzystać w pełni swych zdolności, ale wówczas, gdy nie respektują podstawowych wymogów życia społecznego. ${ }^{8}$

Zdaniem J.J. Thompson, prawo nie może nas zmuszać do moralnego heroizmu, do tego, aby poświęcać własne dobra na rzecz innych. Prawo nie może stawiać ludziom wymagań perfekcjonistycznych. Te wymagania mogą sięgać poziomu Dostatecznie Przyzwoitego Samarytanina, a ewentualne poświęcenie własnych dóbr musi być kwestią wyboru danej jednostki. Argumentacja autorki ukazuje, że zakaz aborcji nakłada de facto na kobietę (która nie chce urodzić dziecka) obowiązek poświęcenia się dla ratowania życia innej osoby w stopniu, który byłby bez wątpienia trudny do zaakceptowania przez większość osób domagających się istnienia takiego zakazu. Urodzenie dziecka wymaga od kobiety podporządkowania mu wielu kolejnych lat życia, często wiąże się to z rezygnacją z własnych planów życiowych, czy innego rodzaju wyrzeczeniami. Urodzenie chorego dziecka to poświęcenia i wyrzeczenia na znacznie większą skalę. W innych sytuacjach życiowych nie jesteśmy skłonni do akceptacji prawa, które by na nas wymuszało pod groźbą sankcji aż takie poświęcenia. Zakaz aborcji to zatem przyjęcie pewnego modelu perfekcjonizmu prawa, to akceptacja przymusu państwowego jako słusznej metody zmuszania obywateli do moralnego heroizmu, który wymaga przedkładania dobra innych ponad dobra własne w sposób przekraczający minimalny poziom poświęceń, jakich można się normalnie domagać od innych w każdej sytuacji. ${ }^{9}$ Wskazuje się też, że „Nie ma sposobu, aby prawo mogło zmusić człowieka, by żył tak godziwie i doskonale, jak jest do tego zdolny". ${ }^{10}$

Często przyjmuje się także, że dla dobra osoby bliskiej ten obowiązek ponoszenia wyrzeczeń jest większy niż wobec obcych osób. ${ }^{11}$ Można się jednak zastanawiać, czy wobec krewnych obowiązki moralne są istotnie wyższe i bardziej rygorystyczne, czy raczej jesteśmy tylko skłonni zaakceptować wyższy niż powszechnie poziom wyrzeczeń i zazwyczaj ludzie dobrowolnie godzą się na ponoszenie różnego rodzaju wyrzeczeń na rzecz bliskich. Należy także zwrócić uwagę na wielki ciężar i dramat

\footnotetext{
L.L. Fuller, Moralność prawa, Warszawa 2004, s. 3.

T. Pietrzykowski, Spór o aborcję..., op. cit., s. 83-85.

L.L. Fuller, Moralność prawa, op. cit., s. 6.

Z uwagi na różne stopnie miłości, zob. np. J. Bocheński, Dzieła zebrane, t. 5, Etyka, Kraków 1995, s. 215 i n.
} 
zwykle samotnej kobiety, gdyż najczęściej kobiety w takiej sytuacji zostają same, wielu mężczyzn po prostu odchodzi.

W aspekcie wolności jednostki trafny jest pogląd, że: „Wolność wyboru żadnej osoby nie może być (...) posunięta tak daleko, aby uzasadniała stwierdzenie, że jeśli naruszenie praw kogoś innego jest zgodne z akceptowaną przez sprawcę aksjologią, to zakazanie jej takiego naruszenia odbiera jej «wolność wyboru»" ${ }^{12}$

W odniesieniu do aborcji wolność wyboru wywołuje spory w kontekście ochrony prawa do życia w demokratycznym państwie prawnym z podstawowym dylematem o status nasciturusa. Pojawia się także pytanie, czy w demokratycznym państwie prawo stanowione powinno być zakorzenione w obiektywnym porządku moralnym, czy też prawo pozytywne pełniąc funkcję organizacji życia państwowego powinno ograniczać się tylko do ochrony wolności negatywnej (wolności „od”) pozostawiając jednostce wolność wyborów etycznych w zakresie obowiązującego prawa. Jednak przyjęcie zasady wolności negatywnej w odniesieniu do życia ludzkiego począwszy od jego poczęcia aż do naturalnej śmierci będzie oznaczać, że człowiek pozbawiony jest prawnych gwarancji życia w jego krańcowych okresach. Takie podejście oznacza również, że prawo do życia nie jest traktowane jako bezwzględna i absolutna wartość, którą należy chronić bez względu na zewnętrzne uwarunkowania, lecz jest rozpatrywane w perspektywie względności ludzkich postaw i zachowań. ${ }^{13}$

$\mathrm{Na}$ płaszczyźnie rozważań dotyczących względów eugenicznych i badań genetycznych brany jest pod uwagę także element ekonomiczny, który wprawdzie nie pojawia się w publicznych dyskusjach, jednak tendencja do komercjalizacji nie omija także i służby zdrowia.

Do głównych czynników sprzyjających komercjalizacji służby zdrowia należą: szybki rozwój technicznych urządzeń medycznych, wzrost specjalizacji oraz zwiększone koszty leczenia, a biznes oddziałuje także na zarządy szpitali, lekarzy, jak i pacjentów. ${ }^{14}$

W diagnostyce prenatalnej element kalkulacji ekonomicznej odgrywa dużą rolę. Przed 30 laty przeprowadzone zostało porównanie kosztów i zysków finansowych wynikających z zastosowania cytogenetycznej diagnostyki prenatalnej zespołu Downa. Jak wykazano, koszt jednego badania w grupie kobiet po 40. roku życia oraz koszt ewentualnego przerwania ciąży wynosił od 0,67 do $0,5 \%$ kwoty potrzebnej w przypadku urodzenia, leczenia oraz wychowania dziecka z zespołem Downa. Wyliczenia zysków i strat w skali kraju, uwzględniające inne grupy

12 T. Pietrzykowski, Spór o aborcję..., op. cit., s. 91.

13 J. Koperek, A. Koperek, Ochrona prawa do życia w demokratycznym państwie prawnym, [w:] Małżeństwo i rodzina wobec aborcji, M.Z. Stepulak (red.), Lublin 2010, s. 84-86.

14 T. Biesaga, Etyczne aspekty komercjalizacji medycyny, „Medycyna Praktyczna” 2005, nr 9(175), s. 19 i n. 
wiekowe, były jeszcze bardziej wymowne i wskazywały na spore oszczędności płynące z niedopuszczenia do urodzenia dzieci chorych. Podobne wyliczenia można znaleźć w fachowych pismach, w wielu krajach, m.in. dla mukowiscydozy, choroby Huntingtona, wad cewy nerwowej, czy właśnie zespołu Downa. Przy stosowaniu diagnostycznych metod molekularnych te dane są jeszcze bardziej wymowne ekonomicznie. ${ }^{15}$

Elementy ekonomiczne badań genetycznych rzadko wysuwane są na pierwszy plan w publicznych debatach. Najczęściej wskazywane jest dobro dziecka, prawo do narodzin w zdrowiu fizycznym i psychicznym, prawidłowy genotyp, współczucie, nadmierne cierpienie, czy jakość życia. Jak jednak podkreśla C. Żekanowski: „od współczucia dla cierpienia łatwo przejść do selekcji osobników, które zasługują na dalszą egzystencję lub których życie można skrócić, tym bardziej iż zarówno koniec, jak i początek życia człowieka mają jedną wspólną cechę: są zazwyczaj kłopotliwe dla otoczenia". ${ }^{16}$

Wracając do kluczowego pytania, możemy zasadniczo przyjąć, że prawo powinno chronić wolność obywateli, a wybory o charakterze etycznym nie powinny być przedmiotem regulacji prawnych. W tym sensie więc prawny zakaz aborcji ze względów eugenicznych stanowi narzucanie określonych przekonań moralnych, etycznych wszystkim obywatelom bez względu na wyznawane poglądy. A zatem bez względu na to, czy dana osoba będzie postrzegać aborcję jako naganną moralnie czy też nie, musi zachowywać się tak, jakby aborcja była niedopuszczalnym złem, podczas gdy pozostawienie wyboru nie wiąże się $\mathrm{z}$ narzucaniem przez prawo określonych przekonań. Matka, która dowiaduje się, że dziecko cierpi na nieuleczalną chorobę wcale nie musi poddać się aborcji, ma bowiem wybór. Jednak delegalizacja aborcji ze względów eugenicznych sprawi, że kobieta będzie musiała urodzić takie dziecko bez względu na przekonania religijne czy ocenę moralną takiego czynu.

Uzasadnienie legalności aborcji ze względów zdrowotnych jest łatwiejsze, gdyż przypadek zagrożenia życia matki możemy zestawić ze stanem wyższej konieczności. W przypadku wskazań eugenicznych sytuacja wygląda inaczej. Ustalenie występowania upośledzenia bądź innej wady płodu jest możliwe dzięki specjalistycznym badaniom prenatalnym. Można więc powiedzieć, że postęp jaki dokonał się w zakresie biotechnologii służy nie tylko ratowaniu życia, ale przyczynia się nadto do jego eliminacji. Podejście eugeniczne zezwala na selekcję i eliminację jednostek, które nie spełniają określonych standardów normalności. Z jednej strony można wskazać, że eugenika dzieli ludzi na lepszych i gorszych, a osoby dotknięte wadami mogą być „przedmiotem” procesu decyzyjnego kobiety. Regulacja tos" 2003 , nr 2, s. 4.

16 C. Żekanowski, Nowa eugenika?, [w:] W. Dyk (red.), Bioetyczne problemy inżynierii genetycznej. Materiały na III krajową konferencję z cyklu: Nauka na przełomie wieków, 5 czerwca 2000 roku, Szczecin 2000, s. 37. 
prawna odbiera takim osobom bezwzględne prawo do życia, pozostawiając wybór kobiecie. Mówi się także o dyskryminacji nienarodzonych osób niepełnosprawnych. Należy jednak wyeksponować aspekt poświęcenia i ofiarności, który pojawia się w przypadku zaistnienia takiej sytuacji i związany z tym dylemat dotyczący poziomu wymagań moralnych, których spełnienie możemy uczynić przedmiotem obowiązku prawnego. Niestety, często w publicznych debatach ten aspekt jest pomijany.

Warto także wspomnieć, że Biuro Zgromadzenia Parlamentarnego Rady Europy odrzuciło projekt rezolucji wzywającej państwa członkowskie do wprowadzenia zakazu przerywania ciąży ze względów eugenicznych. Biuro uznało, że wprowadzenie takiego zakazu stanowiłoby pogwałcenie prawa kobiety do dokonywania świadomego i odpowiedzialnego wyboru.

Jak wynika z powyższych rozważań, problematyka prawnego zakazu aborcji (nie tylko ze względów eugenicznych) to $z$ etycznego punktu widzenia nierozstrzygalny problem. Aktualna regulacja prawna stanowi pewien kompromis w świetle pojawiających się sporów, dylematów i kolizji wartości.

\section{BIBLIOGRAFIA}

1. Biesaga T., Etyczne aspekty komercjalizacji medycyny, „Medycyna Praktyczna” 2005, nr 9(175).

2. Bocheński J., Dzieła zebrane, t.5, Etyka, Kraków 1995.

3. Fuller L.L., Moralność prawa, Warszawa 2004.

4. Kaniowski A., Supererogacja - zagubiony wymiar etyki. Czyny chwalebne w etykach uniwersalistycznych, Warszawa 1999.

5. Koperek J., Koperek A., Ochrona prawa do życia w demokratycznym państwie prawnym, [w:] Małżeństwo i rodzina wobec aborcji, Stepulak M.Z. (red.), Lublin 2010.

6. Petrozolin-Skowrońska B. (red.), Nowa Encyklopedia Powszechna PWN, t. 2, Warszawa 1995.

7. Pietrzykowski T., Spór o aborcję. Etyczne problemy prawa, Katowice 2007.

8. Thompson J.J., In Defence of Abortion, „Philosophy and Public Affairs” 1971, t. 1, nr 1.

9. Zielińska E., Przerywanie ciąży. Warunki legalności w Polsce i na świecie, Warszawa 1990.

10. Żekanowski C., Nowa eugenika?, [w:] W. Dyk (red.), Bioetyczne problemy inżynierii genetycznej. Materiały na III krajową konferencję z cyklu: Nauka na przełomie wieków, 5 czerwca 2000 roku, Szczecin 2000.

11. Żekanowski C., Osoba Osoba i osobnik czyli meandry eugeniki, „Biuletyn Polskiego Stowarzyszenia Rentinitis Pigmentos” 2003, nr 2 


\section{THE ETHICAL AND LEGAL ASPECTS OF ABORTION ON EUGENIC GROUNDS}

This paper presents problem of eugenics, which according to the Act is one of the conditions that allows a legal abortion.

Considerations relate primarily to the problem of women choice of abortion for eugenic reasons, in terms of the postulate banning abortion. In this context, there is in fact a question whether women may be required to make such sacrifices, and whether the law can oblige us to such heroism.

Key words: abortion, the eugenics consideration, ethical choices, the morality of obligation 